AGRICULTURE AND BIOLOGY JOURNAL OF NORTH AMERICA

ISSN Print: 2151-7517, ISSN Online: 2151-7525, doi:10.5251/abjna.2011.2.7.1101.1107

(C) 2011, ScienceHuß, http://www.scihub.org/ABJNA

\title{
Olive seedlings growth as affected by humic and amino acids, macro and trace elements applications
}

\author{
${ }^{1}$ Aml, R.M. Yousef; ${ }^{1} \mathrm{Hala}$, S. Emam and ${ }^{2}$ M.M.S. Saleh \\ 1- Horticultural Crops Technology, National Research Center, Cairo, Egypt \\ 2- Pomology Department, National Research Center, Cairo, Egypt \\ Corresponding author: M.M.S. Saleh: e-mail: mmsssa2000@yahoo.com
}

\begin{abstract}
Spraying Chemlali olive seedlings with humic and amino acids, macro and trace elements, as a single or in different were evaluated during two successive seasons 2008 and 2009. Each treatment was sprayed three times (March, July and September). Shoot and root characteristics also leaf macro and trace elements were discussed. The obtained results indicated that treatment of (Humic acid +amino acids+ macro elements+ trace elements) was the most effective one compared with the other treatment since this treatments gave the best results concerning plant height, brunch numbers, leaf numbers, also it increased plant diameter and leaves area comparing with control. On the other hand, this treatment raised root length and root weight than the control plant.
\end{abstract}

Key words: Chemlali olive seedlings, humic acid, amino acids, macro elements, trace elements

\section{INTRODUCTION}

Olive (Olea europaea L.) is one of the oldest agricultural tree crops of remarkable cultural and economic importance in the Mediterranean Basin also it represents a widely distributed fruit tree in the world (FAO, 2008).It can thrive and produce in new reclaimed areas where other crops can't grow, beside the nutritional importance of olive fruits, either as a table or for oil production. Although olive trees can survive and grow under low soil fertility and water availability conditions, many research studies have been indicating that improving soil fertility and satisfying water requirement are essential factors to obtain a high production. An appropriate fertilization is important during the first years of growth when the tree has to take in nutrients and produce assimilates for the development of its root system and canopy perennial structures and to prepare itself for future fructification. In this period an adequate nutrition stimulates a fast vegetative growth which presumably reduces the juvenile and non-productive phase (Garcia et al., 1999).

The nutrient demand was relatively steady during the different stages of the year for Coratina olive over six years after planting. The demand for $P$ and $K$ is minimal during the first four years after planting and can be fulfilled by naturally supplied soils, Xiloyannis et al. (2000). NPK are considered to be essential elements for plant growth and development of young olive trees, Nawaf and Yara (2006).

On the other side, amino acids as organic nitrogenous compounds are the building blocks in the synthesis of proteins, which are formed by a process in which ribosomes catalyze the polymerization of amino acids, Davies (1982). Several hypotheses have been proposed to explain the role of amino acids in plant growth. Available evidence suggests several alternative routes of IAA synthesis in plants, starting from amino acids, Hashimoto and Yamada (1994). In this respect, Waller and Nowaki (1978) suggested that the regulatory effects of certain amino acids like phenylalanine and ornithine on plant development is through their influence on gibberellins.

Benefits ascribed to the use of humic acid, particularly in low organic matter, alkaline soil, include increased nutrient uptake, tolerance to drought and temperature extremes, activity of beneficial soil micro-organisms and availability of soil nutrients (Russo and Berlyn, 1990), (Senn and Kingman, 1973). Humic materials may also increase root growth in a manner similar to auxins (Donnell, 1973), (Tatini et al., 1991). Fernandez-Escobar et al. (1999) mentioned that, under field conditions, foliar application of leonardite extracts (humic substances extracted) stimulated shoot growth and promoted the 
accumulation of $\mathrm{K}, \mathrm{B}, \mathrm{Mg}, \mathrm{Ca}$ and $\mathrm{Fe}$ in leaves. Abdel Fatah et al. (2008) mentioned that, soil drench application of humic acid to Tifway Bermodagrass hybrid improved growth parameters and NPK leaves contents.

The aim of this study is to evaluate the growth of Chemlali olive seedlings grown under sandy soil conditions as affected by spraying humic and amino acids, some macro and trace elements, each as a single treatment or in different combinations.

\section{MATERIAL AND METHODS}

This study was carried out during two successive seasons, 2008 and 2009 on two years old Chemlali olive seedlings, planted in the experimental station of National Research Centre, at Al-Nobaria district, AlBehera governorate, Egypt. The soil physical and chemical properties are showing in Table (1).

Chemlali olive seedlings were sprayed at three times (March, July and September) with the following materials which sprayed solely or in combinations.

1- Humic acid $0.5 \%(\mathrm{HA})$ : at form of Hammer as a commercial product which contains $86 \%$ potassium humate $+6 \%$ potassium oxide.

2- Amino acids $0.5 \%$ (AA): at form of Pepton $85 / 16$ as a commercial product which contains 18 mixed amino acids. The total percent of amino acids in the product is 85 $\%(16 \%$ as free amino acids in L-a type $)+$ $12 \%$ organic nitrogen $+3.5 \%$ potassium oxide.

3-Macro-elements $0.5 \%$ (ME): at form of potassium dihydrogen phosphate.

4-Trace-elements $0.5 \%$ (TE): $\mathrm{Zn}, \mathrm{Mn}$ and $\mathrm{Fe}$ at chelated form.

Chelated zinc 15\% EDTA- chelated Iron 13\% EDTA - chelated manganese 15\% EDTA.

The control seedlings were sprayed with water only. All seedlings received the same agricultural practices

The field experiment was conducted as follows:-

1-Control

2- Humic acid at $0.5 \%$

3- Amino acids at $0.5 \%$

4- Macro elements at $0.5 \%$

5- Trace elements at $0.5 \%$

6- Humic acid +amino acids
7- Humic acid + trace elements

8- Humic acid + macro elements

9- Amino acids + trace elements

10- Amino acids + macro elements

11- Macro elements + trace elements

12- Humic acid + amino acids + macro elements

+ trace elements

The experiment was arranged in a completely randomized block design with three replicates for each treatment and each replicate was represented by two seedlings.

\section{Vegetative growth Measurements:-}

- Shoot:-

Average number of plant height $(\mathrm{cm})$, stem diameter $(\mathrm{cm})$, number of branches, number of total leaves and total leaf area $\left(\mathrm{cm}^{3}\right)$ were determined at mid of December of each season.

\section{- Root:-}

Root weight (gm), Root length $(\mathrm{cm})$, Root diameter $(\mathrm{cm})$ and Number of roots were measured.

\section{- Leaf minerals determination}

Leaf samples were collected from each seedling to determine $\mathrm{N}, \mathrm{P}, \mathrm{K}, \mathrm{Zn}, \mathrm{Mn}$ and Fe contents according to the method described by Cottenie et al. (1982).

Statistical analysis: The data were subjected to analysis of variance and the method of Duncan's was used to differentiate means, Duncan (1955).

\section{RESULTS AND DISCUSSION}

\section{Vegetative growth Measurements}

\section{- Shoot}

Results in Table (2) showed that, most treatments had a positive effect on plant height when compared with the control. In this respect, treatment No. 12 $(\mathrm{HA}+\mathrm{AA}+\mathrm{ME}+\mathrm{TE})$ recorded the tallest plants in both studied seasons, since it recorded 142.0 and 138.0 $\mathrm{cm}$ in the first and second seasons, respectively. When calculate the average of the two seasons, the same treatment gave the highest value $(140.0 \mathrm{~cm})$ in compared with the other treatments.

As for stem diameter, treatments No. 5 (ME) and No. $12(\mathrm{HA}+\mathrm{AA}+\mathrm{ME}+\mathrm{TE})$ gave the higher values of stem diameter in both studied seasons and the average of the two seasons comparing with the other treatments including the control. In this respect, the average of the two seasons recorded by these treatments was 0.85 and $0.84 \mathrm{~cm}$ for treatment 5 and 12 , respectively. 
Table (1): Some physical and chemical properties of the experimental soil.

\begin{tabular}{|c|c|c|c|c|c|c|c|c|c|c|c|c|c|c|}
\hline \multirow{2}{*}{\multicolumn{3}{|c|}{$\begin{array}{l}\text { Particle size } \\
\text { distribution (\%) }\end{array}$}} & \multirow{2}{*}{$\begin{array}{l}\text { Textur } \\
\text { e } \\
\text { soil }\end{array}$} & \multirow{2}{*}{$\begin{array}{l}\text { Ec } \\
\mathrm{dsm}^{-1}\end{array}$} & \multirow{2}{*}{$\begin{array}{l}\mathbf{p} \\
\mathrm{H}\end{array}$} & \multicolumn{5}{|c|}{ Available nutrients } & \multicolumn{4}{|c|}{ Available nutrients } \\
\hline & & & & & & \multicolumn{5}{|c|}{ (Cation) } & \multicolumn{4}{|c|}{ (Anion) } \\
\hline Sand & Silt & Clay & sandy & 1.5 & $\begin{array}{l}8 . \\
2\end{array}$ & $\mathrm{~N} \%$ & $\mathbf{P} \%$ & $\begin{array}{l}\mathrm{K} \\
\%\end{array}$ & $\begin{array}{l}\text { Ca } \\
\text { meg/l }\end{array}$ & $\begin{array}{l}\mathrm{Mg} \\
\mathrm{meg} / \mathrm{l}\end{array}$ & $\mathrm{CO}$ & $\begin{array}{l}\mathrm{HCO} 3 \\
\mathrm{meg} / \mathrm{l}\end{array}$ & Cl- & SO4 \\
\hline 90 & 5 & 5 & & & & trace & $\begin{array}{l}0.4 \\
4 \\
\end{array}$ & $\begin{array}{l}0.5 \\
7\end{array}$ & 2.65 & 2.4 & - & 3.85 & 53 & 55.65 \\
\hline
\end{tabular}

Table (2): Plant height, plant diameter and branches number as affected by different foliar treatments during the two studied seasons

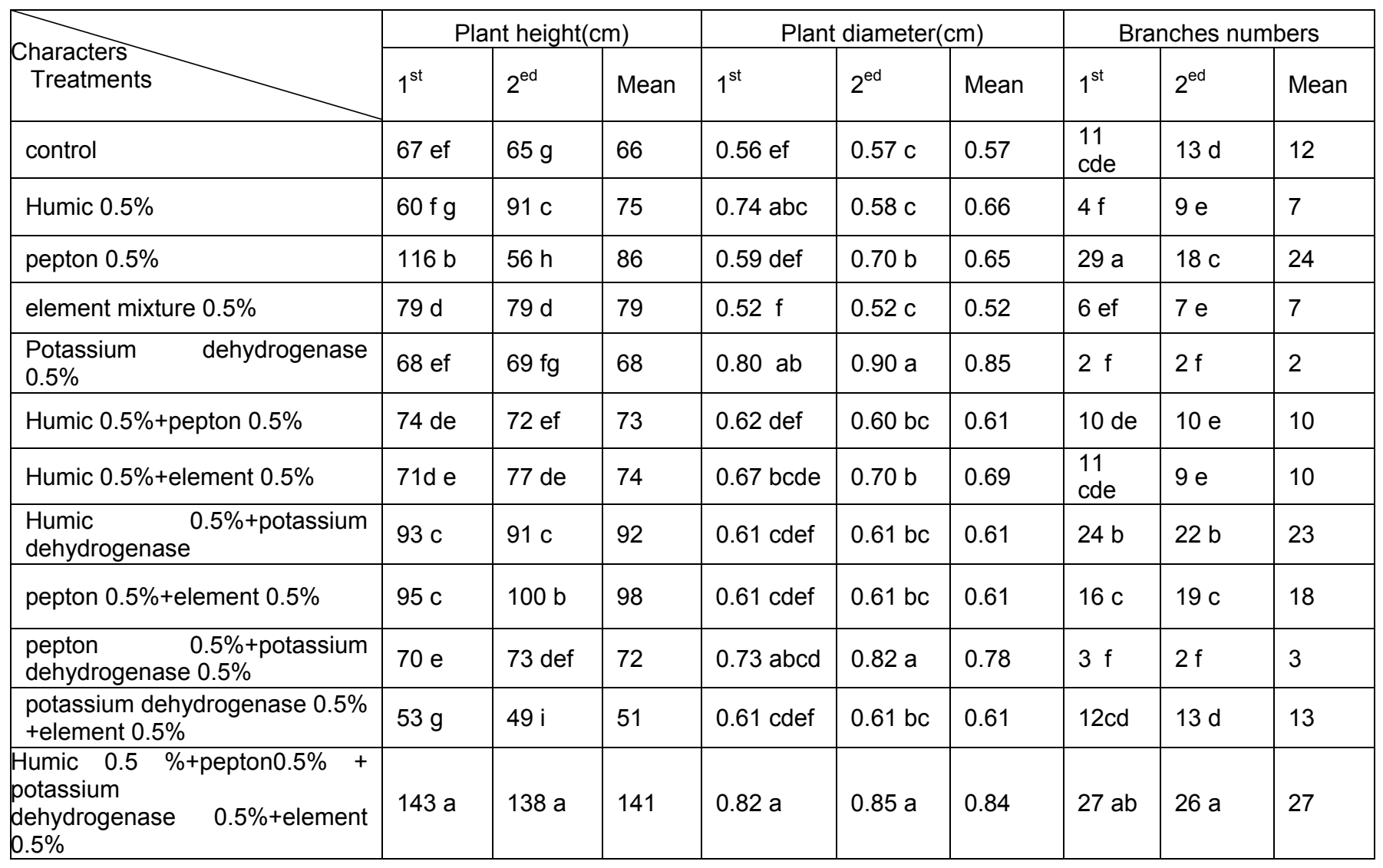


Table (3): Leaves numbers and Leaves area as affected by different foliar treatments during the two studied seasons

\begin{tabular}{|c|c|c|c|c|c|c|}
\hline \multirow{2}{*}{ Treatment } & \multicolumn{3}{|c|}{ Leaves numbers } & \multicolumn{3}{|c|}{ Leaves area $\left(\mathrm{cm}^{2}\right)$} \\
\hline & $1^{\mathrm{st}}$ & $2^{\mathrm{ed}}$ & Mean & $1^{\text {st }}$ & $2^{\mathrm{ed}}$ & Mean \\
\hline Control & $103 \mathrm{~g}$ & $105 \mathrm{i}$ & 104 & $11 \mathrm{~g}$ & $15 \mathrm{~g}$ & 13 \\
\hline Humic $0.5 \%$ & $146 \mathrm{~d}$ & $214 \mathrm{~b}$ & 178 & $33 \mathrm{~b}$ & $36 \mathrm{~b}$ & 35 \\
\hline Pepton $0.5 \%$ & $191 \mathrm{~b}$ & $117 \mathrm{~h}$ & 154 & $12 \mathrm{~g}$ & $16 \mathrm{~g}$ & 14 \\
\hline Element mixture $0.5 \%$ & 127 e & $128 \mathrm{e}$ & 128 & 24 cde & $28 \mathrm{~d}$ & 26 \\
\hline Potassium dehydrogenase $0.5 \%$ & $114 \mathrm{f}$ & $118 \mathrm{gh}$ & 116 & $27 \mathrm{bcd}$ & $32 \mathrm{c}$ & 30 \\
\hline Humic $0.5 \%+$ pepton $0.5 \%$ & $108 \mathrm{fg}$ & $120 \mathrm{~g}$ & 114 & 20 ef & $25 \mathrm{e}$ & 23 \\
\hline Humic $0.5 \%+$ element $0.5 \%$ & $129 \mathrm{e}$ & $149 \mathrm{~d}$ & 139 & 18 ef & $24 \mathrm{e}$ & 21 \\
\hline Humic $0.5 \%+$ potassium dehydrogenase & $168 \mathrm{c}$ & $168 \mathrm{c}$ & 168 & $15 \mathrm{fg}$ & $19 \mathrm{f}$ & 17 \\
\hline Pepton $0.5 \%+$ +element $0.5 \%$ & $113 \mathrm{f}$ & $118 \mathrm{gh}$ & 116 & 22 de & $25 \mathrm{e}$ & 24 \\
\hline Pepton $0.5 \%+$ potassium dehydrogenase $0.5 \%$ & $125 \mathrm{e}$ & $98 \mathrm{j}$ & 112 & $11 \mathrm{~g}$ & $15 g$ & 13 \\
\hline Potassium dehydrogenase $0.5 \%+$ element $0.5 \%$ & $114 \mathrm{f}$ & $124 \mathrm{f}$ & 119 & $43 \mathrm{a}$ & $46 \mathrm{a}$ & 45 \\
\hline $\begin{array}{lcc}\text { Humic } & 0.5 \%+\text { pepton } & 0.5 \% \text { potassium } \\
\text { dehydrogenase } & 0.5 \%+\text { +element } 0.5 \% & \\
\end{array}$ & $291 \mathrm{a}$ & 293 a & 292 & 28.bc & $32 c$ & 30 \\
\hline
\end{tabular}

Regarding number of branches per seedling in the first season, it is observed that treatment No. 3 (AA) showed the highest number followed without significant differences by treatment No. 12 $(\mathrm{HA}+\mathrm{AA}+\mathrm{ME}+\mathrm{TE})$, while in the second season, treatment No. 12 recorded the highest number followed in decreasing order by treatment No. 8 (HA+ME). However, the highest value for the average of the two seasons was recorded by treatment No. 12, since it gave 26.67 branches.

Concerning number of the leaves per seedling, data in Table(3) showed that, the highest value was obtained by treatment No. 12 in both studied seasons, also the average of the two seasons compared with all other treatments. Since this treatment recorded 291, 293 and 292 leaves for the first, second and the average of the two seasons, respectively.
Leaves area was affected by different treatments, since treatment No. 11 gave the highest value in the first and second seasons $\left(42.7\right.$ and $46.3 \mathrm{~cm}^{3}$, respectively). The same treatment recorded the highest value for the average of the seasons.

\section{Root}

Results in Fig (1) showed that root weight was affected by different treatments. In this respect, treatment No. 5 (ME) increased root weight than all other treatments and recorded the highest weight followed by treatment No. $2(\mathrm{HA})$ and No. 12 (HA+AA+ME+TE).

Root length was affected by different treatments, since treatment $12(H A+A A+M E+T E)$, No. 10 (AA+ME) and No. 5 (ME) enhanced root length than the other treatments.

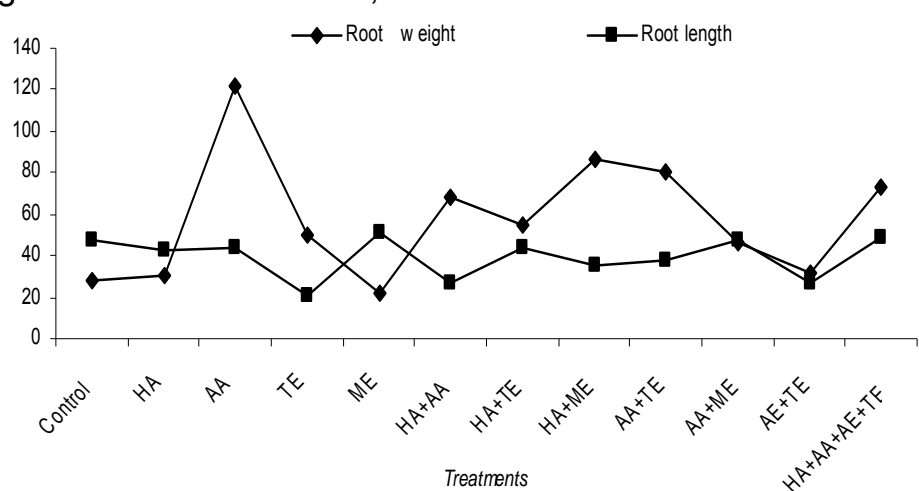

Fig (1) Root weight and root length of Chemlali olive seedling as affected by different foliar treatments during the two studied seasons 
As for root diameter Fig (2), it seems that different treatments had no effect on this parameter. Regarding number of roots per seedling, it is observed that treatment $7(\mathrm{HA}+\mathrm{ME})$ recorded the highest value, followed by treatment No. $10(A A+M E)$ and No. 3 (AA)

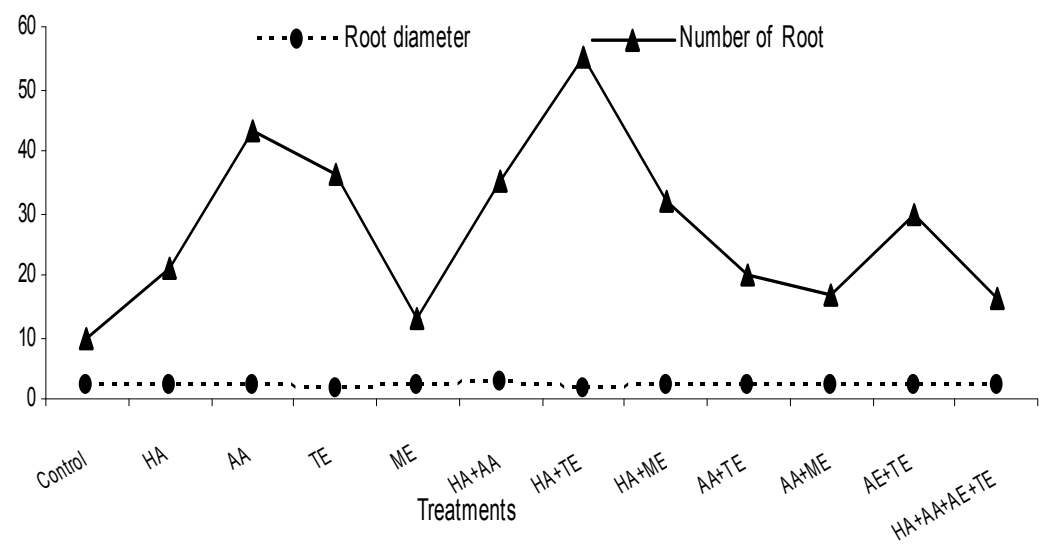

Fig (2) Root diameter and number of root of Chemlali olive seedling as affected by different foliar treatments during the two studied seasons

\section{- Leaf minerals determination}

1. Macro elements

Fig (3) shows that nitrogen content in the leaves was affected by different treatments, since treatment No. $10(A A+M E)$ increased nitrogen percentage in the leaves and recorded the highest value followed by treatment No. 3 (AA) and the control.
As for phosphorus, treatment No. 12 (HA+AA+ME+TE) increased phosphorus content followed by treatment No. 5 (ME) and No. 8 (HA+ME). Potassium content in the leaves was slightly increased by treatment No. 8 (HA+ME) than the other treatments.

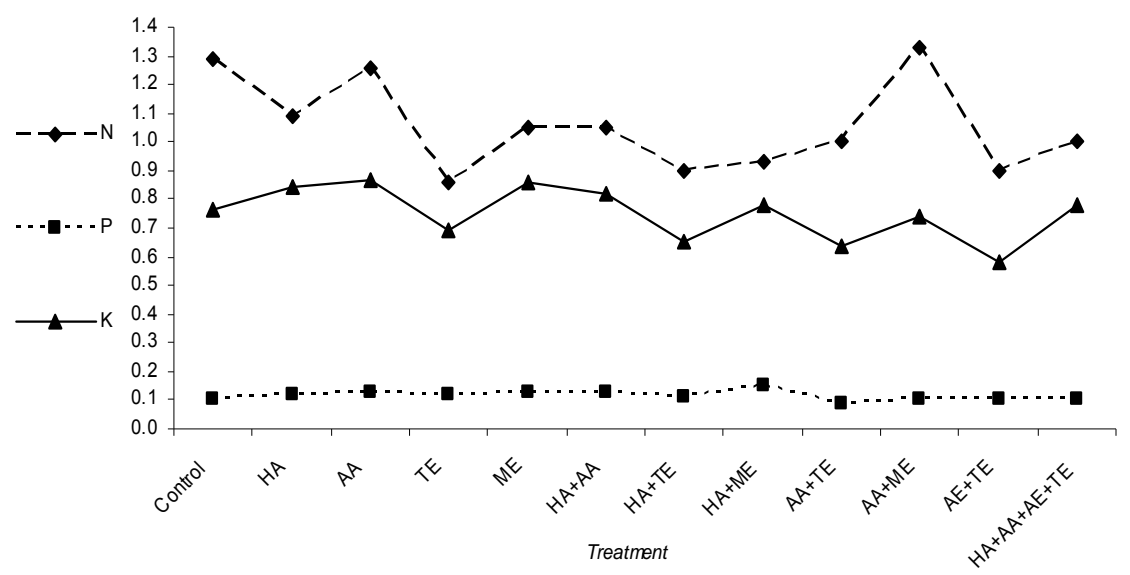

Fig. (3)Macro elements in leaves of Chemlali olive seedling as affected by different foliar treatments during the two studied seasons 


\section{Trace elements}

Fig (4) showed that $\mathrm{Zn}$ content in the leaves, more or less was not affected by any treatment. While as $\mathrm{Mn}$ value was slightly enhanced by treatment No. 4 (TE) than the other treatments. Concerning Fe content in the leaves, it was increased by treatment No. 9 $(\mathrm{AA}+\mathrm{TE})$ and No. $3(\mathrm{AA})$, also No. 6 (AA+HA).

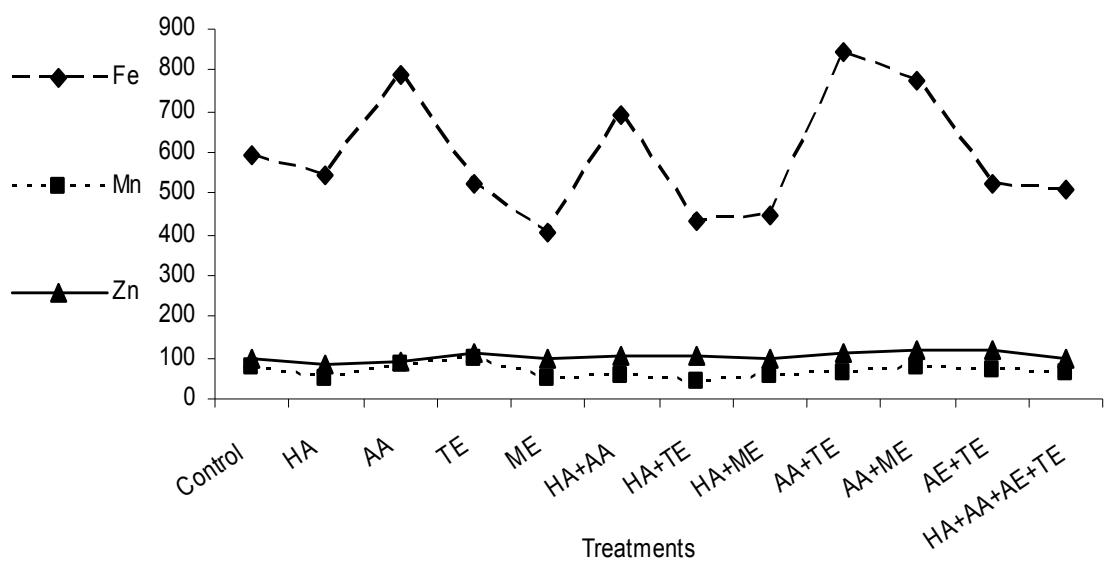

Fig. (4) Trace elements in leaves of Chemlali olive seedling affected by different foliar treatments during the two studied seasons

From the abovementioned results, it is clear that treatment No. 12 (humic acid + amino acids + macro elements + trace elements) was the most effective one compared with the other treatments. Since this treatment gave the best results concerning plant height, branch numbers, leaves number, also it increased plant diameter and leaves area comparing with the control. On the other hand, this treatment raised root length and root weight than the control plant.

However, the obtained results are in harmony with those obtained by Fernandez-Escobar et al. (1999) who reported that humic acid treatments stimulated plant growth of young olive plants. This may be due to the effect of humic acid in increasing root growth in a manner similar to auxin (Donnell, 1973), also, increasing nutrient uptake (Russo and Berlyn, 1990), (Senn and Kingman, 1973) which reflected on promoting the accumulation of leaf mineral contents (Fernandez-Escobar et al. (1999) and consequently stimulated plant growth. On the other hand, the effect of amino acids may be due to their role on synthesis of proteins in the plant (Davies, 1982). However, Hashimoto and Yamada (1994) reported that several alternative routes of IAA synthesis in plants starting from amino acids. Also Waller and Nowaki (1978) suggested the regulatory effects of certain amino acids like phenylalanine and ornithine, on plant development is through their influence on gibberellins. According to Ghanta and Metra (1993), improving growth characters in response to the foliar application of micronutrients may be due to their positive action on increasing cell division in the meristematic tissues and accelerating carbohydrates and proteins formation. Also, these elements play an important role in the multi-biological processes such as the role of $\mathrm{Zn}$ in the synthesis of IAA (Nijjar, 1985). Ben Mimoun et al. (2004) found that potassium foliar spray on olive trees significantly increased leaf area, also raised potassium content in the leaves. On the other hand, Hassan et al. (2010) reported that mineral nitrogen + humic acid treatment increased nitrogen content in olive plants.

\section{REFERENCES}

Abdel Fatah H. G; B A. El Sayed and S.M. Shahin (2008): The role of humic acid in reducing the harmful effect of irrigation with saline water on Tifway turf. J. Bio. Chem. Environ. Sci. Vol. 3(1):75-89. 
Ben Mimoun, M.; O. Loumi; M. Ghrab; K. Latiri and R. Hellali (2004): Foliar potassium application on olive tree. IPI regional workshop on Potassium and Fertigation development in West Asia and North Africa; Rabat, Morocco, 24-28 November.

Cottenie, A.; M. Verloo; L. Kiekens; G. Velgle and R. amerlynuck, (1982). Chemical Analysis of Plant and Soil, 43- 51. Laboratory of Analytical and Agroch. State Univ. of Belgium, Gent.

Davies, D.D., (1982). Physiological aspects of protein turnover. Encycl. Plant Physiol. New Series, 14 A (Nucleic acids and proteins: structure, biochemistry and physiology of proteins, Eds., Boulter, D. and B Partier, Springer Verlag, Berlin, Heidelberg \& New York, pp: 190-228.

Donnell, R.W., (1973). The auxin-like effects of humic preparations from leonardite. Soil Sci., 116: 106-112.

Duncan, D.B., (1955): Multiple range and multiple "F" tests. Biometrics, 11: 1-42.

FAO. (2008). The Statistical Database (FAOSTAT). Rome, Italy: Food and Agriculture Organization of the United Nations. Available in: http://faostat.fao.org [8 June, 2009].

Fernandez-Escobar R.; M. Benlloch; D. Barranco; A. Duenas and J.A. Gutérrez Ganan (1999): Response of olive trees to foliar application of humic substances extracted from leonardite. Scientia Horticulturae, Vol. 66, (3-4), 191-200.

Garcia J.K.; J. Linan; R. Sarmiento; A. Troncoso, (1999). Effects of different $\mathrm{N}$ forms and concentrations on olive seedlings growth. Acta Hort. 474: 323-327.

Ghanta, P.K. and S.K. Mitra, (1993). Effect of micronutrients on growth, flowering, leaf nutrient content and yield of banana cv., Giant cavandishii. Crop Research. 2: 284-287.

Hashimoto, T. and Y. Yamada, (1994). Alkaloid biogenesis: Molecular Aspects. Ann. Rev. Plant Physiol. Plant Mol. Biol., pp: 245-257.

Hassan, H.S.A.; Laila, F. Hagag; M. Abou Rawash; H. ElWakeel and A. Abdel-Galel, (2010). Response of Klamata olive young trees to mineral, organic nitrogen fertilization and some other treatments. Journal of American Science, 6(10): 393-399.

Nawaf, M. Ferihat and Yara K. Masa'deh (2006): Response of two-year-old tree of four olive cultivars to fertilization. Amrican-Erasian J. Agric. \& Environ. Sci., 1 (3): 185-190.

Nijjar, G.S., (1985). Nutrition of fruit trees. Kalyani Publishers New Delhi, pp. 50-100, India.

Russo, R.O. and G.P. Berlyn, (1990). The use of organic biostimulants to help low input sustainable agriculture. J. Sustainable Agric., 1(2): 19-42.

Senn, T.L. and A.R. Kingman, (1973). A review of humus and humic acids. South Carolina Agricultural Experiment Station, Clemson, SC. Research Series Report No. 145.

Tatini, M.; P. Bertoni; A. Landi and M.L. Traversi, (1991). Effect of humic acids on growth and biomass portioning of container-grown olive plants. Acta Hort, 294: 75-80.

Waller, G.R. and E.K. Nowaki, (1978). Alkaliod, Biology and Metabolism in Plants. Plenum Press, New York, pp: 85-247.

Xiloyannis C.; G. Celano; A.M. Palese; B. Dichio and V. Nuzzo (2000): Mineral nutrient uptake from the soil in irrigated olive trees, cultivar Coratina, over six years after planting. Acta Horticulturae 586: 